\title{
REVIEW
}

\section{The kiss-1-kisspeptin-gpr54 complex: a critical modulator of GnRH neurons during pubertal activation}

\author{
César Alberto Meza-Herrera ${ }^{1}$, Francisco Gerardo Veliz-Deras ${ }^{2}$, Maria Wurzinger ${ }^{3}$, \\ Bernardo López-Ariza1, Gerardo Arellano-Rodriguez ${ }^{2}$, Rafael Rodriguez-Martinez ${ }^{2}$ \\ ${ }^{1}$ Universidad Autónoma Chapingo, Unidad Regional Universitaria de Zonas Áridas, Bermejillo, Durango, \\ Mexico \\ ${ }^{2}$ Universidad Autónoma Agraria Antonio Narro, Unidad Laguna, Mexico \\ ${ }^{3}$ BOKU - University of Natural Resources and Applied Life Sciences, Austria
}

Received $10^{\text {th }}$ August 2009.

Published online $1^{\text {st }}$ December 2009.

\begin{abstract}
Summary
Establishment of the hypothalamic-hypophyseal-gonadal function is dependent on the highly controlled and dynamic interactions between regulatory signals from the brain, pituitary and gonads, all of them leading to the attainment of reproductive capacity, where a coordinated and timely activation of GnRH neurons must occur. The GnRH neurons extend their neurosecretory axons to the hypothalamus where GnRH is released into the pituitary portal vessels to elicit the secretion of LH and FSH, which in turn, will promote gonadal development and support reproductive physiology. Genetic studies have demonstrated that disabling mutations and targeted deletions of the G-protein-coupled receptor (GPR54) generated hypogonadotropic hypogonadism. This link between GPR54 and reproduction, generated attention to the natural ligands of the GPR54 receptor, known as kisspeptins, which are translational products of the hypothalamic gene KiSS1. Recent advances in kisspeptin research have defined a major role of this molecule in controlling the onset of the reproductive function observed at puberty. The aim of this review is to highlight the basic endocrine and genetic concepts involved in the establishment of the hypothalamic-hypophyseal-gonadal axis function which promotes the onset of the reproductive function during puberty. The review highlights what is currently known about the kisspeptin-GPR54 signalling system in the activation of the GnRH neurons.
\end{abstract}

Key words: reproductive axis; GnRH neurons; kisspeptin-GPR54 system; puberty

\section{INTRODUCTION}

The onset of the reproductive function in peripuberal stages and the reproductive capacity in adult stages is critical to the survival of the species. Therefore,

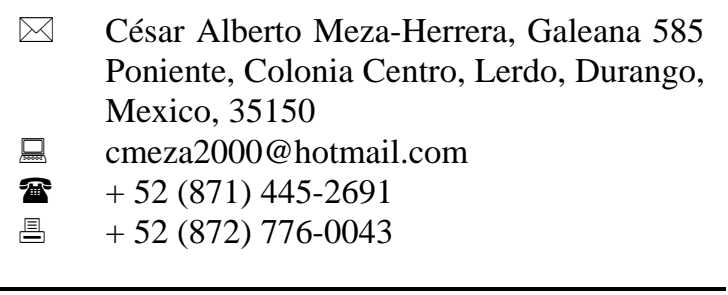

physiological homeostasis dictates optimal conditions for reproductive success, and any disturbance of this balance may affect the function of the gonadotropin releasing hormone $(\mathrm{GnRH})$ neurones (Meza-Herrera et al. 2009). These perturbations may include alterations in the signals dictated by stress, nutritional imbalance, body weight and some neurological alterations. For these reasons, changes in other neuroendocrine systems may directly influence the hypothalamic-hypophyseal-gonadal axis, through direct regulation of GnRH (Belsham and Lovejoy 2005, Ebling 2005, Maffucci and Gore 2009).

Certainly, the establishment of the pubertal process does not only depend on chronological age (Bronson 2001, DiVall and Radovick 2009). Rather, 
the neurotransmitter and neuromodulatory systems that regulate $\mathrm{GnRH}$ secretion and release, also relay on information about metabolic fuels, body energy reserves, somatic development and, for many species, information about season and social environment (Teresawa and Fernández 2001, Arechiga-Flores et al. 2004, Meza-Herrera et al. 2009, Veliz et al. 2009). Clear links exist between metabolic fuel (glucose, pyruvate and lactate) availability and the reproductive function (Cheung et al. 1997, Ebling 2005).

In fact, changes in the blood levels of metabolic hormones are important signals that inform the nutritional status of mammals (Meza-Herrera et al. 2007, 2008, Gamez-Vazquez et al. 2008). An explanation is that the response to a feed supplementation alters glucose, insulin, leptin or IGF-I and probably other metabolic hormones (Meza-Herrera et al. 2004, 2008, 2009, Muñoz-Gutierrez et al. 2005, Scaramuzzi et al. 2006, Guerra-García et al. 2009).

Nonetheless, activation of the hypothalamic-hypophyseal-gonadal axis is a required step in order for puberty to occur. Secretion of GnRH is significantly reduced before puberty. Certainly, in the early stages of the puberty process, the hypothalamic gonadostat is still depressed while the amplitude of $\mathrm{GnRH}$ pulses is increasing. Later on, the concentration of the gonadotropic follicle stimulating (FSH) and luteinizing ( $\mathrm{LH})$ hormones, gradually increases as puberty advances. This gonadotropic input stimulates follicular growth and maturation while oestrogen production by the ovaries also increases (Apter 1997, Roth et al. 2001, Apter and Hermanson 2002, Aparicio 2005).

The extremely efficient negative feedback system from the ovarian steroids is particularly active before the puberal process begins. Nonetheless, as the puberal stage advances, a highly efficient positive feedback signal from the ovarian steroids is activated, promoting the establishment of normal cyclicity by the end of this stage. Because of that, an efficient transition from the prepubertal stage to total maturation at puberty is an indispensable prerequisite for the establishment of the reproductive function (Aparicio 2005, Teresawa 2005, Clarkson and Herbison 2006, Messinis 2006, Ojeda et al. 2006a, b, DiVall and Radovick 2009).

The aim of this review is to highlight the endocrine and genetic discoveries involved in the establishment of the hypothalamichypophyseal-gonadal axis function which promotes the onset of the reproductive function during puberty. To accomplish that, some basic aspects of the function of the hypothalamic-hypophyseal-gonadal axis, as well as of the role of the novel system kisspeptins (KP) and their cognate receptor GPR54 acting as critical regulators of the onset of puberty will be discussed. This review includes recent advances in the molecular consequences of KP action on GnRH neurons as well as comments how these neuronal circuits are integrated.

\section{NEUROENDOCRINOLOGY OF REPRODUCTION: REGULATION OF THE HYPOTHALAMIC-HYPOPHYSEAL- GONADAL AXIS}

\section{The GnRH pulse generator and gonadotrophin} release: Overview and recent insights

The initiation of the reproductive function is a centrally regulated process and the detailed mechanisms of its function are still unknown. It is recognized, however, that increases in the activity of the pulse generator of the GnRH, and then in the pulsatile secretion of gonadotrophins FSH and $\mathrm{LH}$ take place. During puberty, the pulsatile secretion of gonadotrophin is increased during the day, promoting normal gonadal development and function; the latter because of the activation of the GnRH pulse generator (Aparicio 2005, Teresawa 2005, Clarkson and Herbison 2006, Messinis 2006, Ojeda et al. 2006a, Prevot et al. 2007).

GnRH is a decapeptide mainly synthesized in the preoptic area (POA) and the mediobasal (MB) hypothalamus. Up to sixteen different forms of $\mathrm{GnRH}$ have been isolated (Latimer et al. 2000) and the amino acid sequence of the hypophysiotrophic $\mathrm{GnRH}$ (pGlu-His-Trp-Ser-Tyr-Gly-Len-Ser-Pro-Gly- $\mathrm{NH}_{2}$ ) has been found almost identical in most mammals (Ramakrishnappa et al. 2005), with the exception of the guinea pig (Jimenez-Linan et al. 1997). Only a few GnRH neurons, scattered through the POA and adjacent areas with an estimated total population of 2,400 GnRH cells have been reported in the adult brain (Marshall and Goldsmith 1980, Clarke and Pompolo 2005).

\section{Ontogeny of GnRH neuron development in the brain}

According to Wray (2001), the GnRH neurons originate from the olfactory placode of the embryo, later on, the cells migrate to and colonize the basal forebrain, around the POA, and the mediobasal hypothalamus. Some studies have demonstrated that the largest GnRH concentration is found in the median eminence (ME) of the mammalian species, where it is stored in neuronal terminals prior to release into the hypophyseal portal blood (Lehman et 
al. 1986, Clarke and Pompolo 2005), although a discrete number of GnRH cells in the arcuate nucleus may be relevant to the basal secretion of this peptide in sheep (Boukhliq et al. 1999).

As mentioned by Clarke and Pompolo (2005), the anatomical connections between the hypothalamus, median eminence and the hypophysis can be considered a masterpiece of design which allows an exquisite control of the gonadotropes in the pituitary. In fact, GnRH neurons project to the external-secretory zone of the ME, where terminals gain a close proximity to the capillary bed of the hypophyseal portal system (Clarke and Pompolo 2005). Changes in the pattern release of GnRH will determine, in turn, the onset of puberty as well as the maintenance of the reproductive function in the adult state. According to Heger et al. (2007), transsynaptic changes involve a coordinated increase in excitatory inputs but a reduction in inhibitory influences (Teresawa and Fernandez 2001). In the same way, the glial component of this neuronal system is mainly facilitatory and exerts its actions through growth factors upon GnRH secretion (Prevot et al. 2007).

\section{Extra-hypothalamic GnRH and GnRH receptor expression in different tissues}

Interestingly, although the hypothalamus and pituitary are the principal source and target site for $\mathrm{GnRH}$, several reports have recently suggested extra-hypothalamic GnRH and GnRH receptors in various tissues such as ovaries (follicle and corpus luteum), uterus, placenta, endometrium, oviducts, testes, prostate and mammary glands (Ramakrishnappa et al. 2005, Singh et al. 2008). The presence of GnRH-R in these tissues is intriguing and warrants the evaluation of a functional role of this ligand-receptor system in the regulation of the reproductive process.

\section{Functional biology of GnRH neurones upon the hypothalamic-hypophyseal axis}

In adult animals, GnRH is released in a pulsatile fashion, every $60 \mathrm{~min}$, inside the portal system which connect to the hypophysis. In young animals, however, the pulse interval is much more larger, 90 to 120 minutes, and it is the acceleration of the frequency of the pulse and the increase in the amplitude of the pulse, as well as the total $\mathrm{GnRH}$ concentration, that activates transduction signals to promote both synthesis and intermittent release of LH and $\mathrm{FSH}$, generating the onset of the pubertal process (Aparicio 2005, Teresawa 2005, Clarkson and Herbison 2006, Messinis 2006, Ojeda et al. 2006a).

In the gonadotrope, GnRH binds to a single class of $G$ protein coupled receptor, which is a member of the large superfamily of seven transmembrane domain receptors that bind to $G$ proteins (Ramakrishnappa et al. 2005) and initiates a series of physiological events leading to the synthesis and release of LH and FSH. Upon binding to its receptor, GnRH activates the enzyme phospholipase-C, via the generation of different second messengers such as dyacilglycerol and inositol. Then, the activation of protein kinase- $C$ and the release of $\mathrm{Ca}$ from the intracellular space occur, generating both the synthesis and the secretion of LH and FSH. The GnRH-R expression is regulated by the GnRH itself as well as by gonadal steroids (Apter 1997, Roth et al. 2001, Apter and Hermanson 2003, Ramakrishnappa et al. 2005, Clarkson and Herbison 2006, Messinis 2006, Ojeda et al. 2006a).

\section{The GnRH system at prepuberal and peripuberal stages}

Prior to puberty, GnRH secretion is markedly suppressed, while at the beginning of puberty, the hypothalamic gonadostat is also depressed and the amplitude of the GnRH pulses increases. The hormonal level of $\mathrm{LH}$ and FSH are gradually increased during puberty, stimulating both follicular maturation and ovarian oestrogen production. The negative feedback of oestradiol is powerful only prior to puberty, while the oestradiol positive feedback is turned on for the first time at the end of puberty. As a result, the normal cyclicity of the ovarian function is established so that steroidal and non-steroidal hormones mediate the effect of the ovaries upon the hypothalamic-hypophyseal system. Both, oestradiol and progesterone are important regulators of the FSH and LH secretion, while inhibin plays a paramount role in the control of FSH secretion (Apter 1997, Aparicio 2005, Clarke and Pompolo 2005, Clarkson and Herbison 2006, Messinis 2006).

The neurons releasing GnRH, represent the critical cellular type that, once activated, induce puberty (Clarkson and Herbison 2006). For this reason, an appropriate expression of the GnRH-R in the gonadotrophs is critical for the signalling and secretion of gonadotrophins in order to mediate, in this way, ulterior sexual development (Zapatero-Caballero et al. 2004). The GnRH neurons are important not only because they are involved in the onset of the reproductive function, but also in the development of neuromodulatory functions in the adult (Aparicio 2005, Clarke and Pompolo 2005, Whitlock et al. 2006).

The discovery of the ligand activator of the signalling upstream route from $\mathrm{GnRH}$ linked to the G-protein receptor gives more significance to the central role that the hypothalamus plays in the regulation of puberty (Clarkson and Herbison 2006, 
Hughes and Kumanan 2006). The onset of puberty is associated with an increase in the amplitude and frequency of LH. Later on, a progressive increase in the LH pulsatility occurs during the day, while a progressive reduction is observed of the amplification which previously occurred during the night. In females, prepubertal FSH concentrations are relatively high, and a continuous process of follicular development and atresia occurs, observing relatively high concentrations of oestradiol. Ovarian steroidogenesis is activated only after this initial increase in LH, leading to increases in oestrogen secretion. Thereafter, both follicular development and maturation occur, under FSH stimulation (Apter 1997, Suttie et al. 1998, Aparicio 2005).

\section{FUNCTIONAL BIOLOGY OF THE KiSS-1, KISSPEPTINS AND GPR54 SYSTEM}

\section{The KiSS-1, KP and GPR54 system: A basic approach}

The hypothalamic gene KiSS1, encodes a 54 amino acid precursor that is cleaved to a family of peptides known as kisspeptins, also known as metastin, (Popa et al. 2005, Brown et al. 2008) and has been considered as an essential integrator of peripheral cues including the gonadal steroids as well as nutritional status, which act, in turn, upon the activation of GnRH neurons (Aparicio 2005, Popa et al. 2005, Tena-Sempere 2006 a, b, c). Kisspeptin and its receptor GPR54 which is linked to G-proteins, have emerged as key elements in the regulation of GnRH secretion (Aparicio 2005, Gottsch et al. 2006, Tena-Sempere 2006a, b, c, DiVall and Radovick 2009).

Since GPR54 mutations do not prevent the migration of GnRH neurons from the olfactory placode to the forebrain, it is suggested that GPR54 is required for the normal physiological function of GnRH neurons after they have migrated and innervated their targets (Popa et al. 2005). The GPR54 gene is expressed in several peripheral tissues such as the placenta, pancreas, kidney, testis, anterior pituitary, and the brain, most notably the hypothalamus, preoptic area (POA), midbrain, hippocampus, amygdala and medulla (Lee et al. 1999, Kotani et al. 2001, Muir et al. 2001).

The KiSS-1, KP \& GPR54 system and the reproductive brain

Kisspeptins were originally identified as tumoral metastasis suppressor peptides bound to the G-protein linked GPR54 receptor (Castellano et al. 2006a, b,
Ojeda et al. 2006b). However, mutations in the GPR54 gene have been related to an absence in the onset of puberty and hypogonadotrophic hypogonadism (Castellano et al. 2006a, b, Tena-Sempere, 2006c). The proteolytic cleavage of the KiSS1 primary product generates the decapeptide kisspeptin-10, which is the minimal kisspeptin sequence necessary for receptor activation, has shown itself to be a very potent agent promoting LH release (Ojeda et al. 2006b, Kadokawa et al. 2008, Suzuki et al. 2008) and which has also demonstrated direct action upon the secretion of GH and PRL from cultured bovine pituitary cells (Kadokawa et al. 2008).

KiSS1 mRNA has been detected in several peripheral sites including the hypothalamus, hypophysis, ovary, placenta and adipose tissue (Castellano et al. 2006a, b, Gutierrez-Pascual et al. 2007, Brown et al. 2008). Since GPR54 is highly expressed in the pituitary gland (Gutierrez-Pascual et al. 2007), kisspeptin should be secreted from kisspeptin neurons into the hypophyseal portal blood to act on the hypophysis, and may also exert autocrine and paracrine actions in the pituitary (Kadokawa et al. 2008).

An element involved in synapses formation, SynCAM, is an immunoglobulin-like adhesion molecule previously recognized as a tumour suppressor molecule in lung cancer. It has been proposed that both SynCAM and kisspeptin conform a network of genes which, besides their function as suppressor molecules of tumoral metastasis in the brain, also act as integrator elements in neuron-to-neuron and glia-to-neuron communication, building a functional unit able to initiate the puberty process (Ojeda et al. 2006b).

The KiSS-1, KP, GPR54 complex: A signalling system modulating the onset of puberty

Hypogonadotrophic hypogonadism has been observed when mutations in the GPR54 receptor expression occur, indicating that signalling through this receptor is a prerequisite for sexual maturation. The central administration of kisspeptin stimulates secretion of both GnRH and gonadotrophins in prepubertal and adult animals. In the same way, increases in the expression of the KiSS1 and GPR54 genes have been observed during the pubertal development, while activation of GPR54 by kisspeptin administration is enough to induce the activation of the gonadotrophic axis in immature animals (Aparicio 2005, Popa et al. 2005, Gottsch et al. 2006, Tena-Sempere 2006a, b).

Neurons expressing kisspeptin are direct targets of the steroid feedback action, both positive and negative, which differently regulate the mRNA KiSS1 
expression in several brain areas, and have again a relevant role in the establishment of puberty. It has been suggested that there is a double site of kisspeptin action in the brain, either in the hypothalamic-hypophyseal region or in the median eminence, an area located outside the blood brain barrier.

The available data suggest that kisspeptins are synthesized in neurons located in the anteroventral periventricular nucleus and the arcuate nucleus. Both populations are considered to be involved in the control of gonadotropes. Besides that, KP nerve terminals and receptors are found in other hypothalamic areas suggesting that KP could be involved in the regulation of other yet unknown homeostatic or neuroendocrine functions (Mikkelsen and Simonneaux 2009). In addition, KP-neurons have been located in discrete subsets of the preoptic area and the arquate nuclei of the brain; those neurons containing the GPR54 receptors are more diffusely distributed and include GnRH neurons as well as the adenohypophysis. In primates, the KiSS1 and GPR54 mRNA levels significantly increase in the hypothalamus at the time of puberty suggesting that an increase in the GPR54 mediated signal contributes to the pubertal activation of GnRH secretion (Ojeda et al. 2006b).

Prior to puberty, a pulsatile increase in $\mathrm{GnRH}$ secretion is observed due to coordinated changes in the trans-synaptic communication and to the interaction between neuron-to-glial cells. As the excitatory signal from neurons and glial cells increases, a reduction in the inhibition in the trans-synaptic tone is observed, generating the pubertal activation of GnRH secretion. The neuronal systems more invoked in this process include glutamate and the peptide kisspeptin which exert neurotransmission and neuromodulation processes, while the most important inhibitory signal is provided by GABAtergic and opiatergic neurons (Ojeda et al. 2006b).

Glial cells and GnRH neurons display a morphologic and functional relationship which depends on growth factors that act through serine-treonine-kinase receptors as the transforming growth factor (TGFB1). These growth factors send their signal through receptors with tyrosine-kinase activity such as the insulin-like growth factors (IGF-1), the fibroblast growth factor, the members of the epidermal growth factor family, the TGFalfa and the neuregulins. A complete discussion on the roles of these growth factors has been previously presented by Garcia-Segura and McCarthy (2004), Gill et al. (2004), and Ojeda (2006a, b).
The KiSS-1, KP and GPR54 system: A sensory system to translate environmental cues

KiSS1 is also involved in the metabolic control of the reproductive function; the expression of the hypothalamic gene KiSS1 is negatively regulated under conditions of negative energy balance, and administration of kisspeptin is capable of reversing the hypogonadotrophic stage observed under scenarios of undernutrition and metabolic disturbance (Aparicio 2005, Castellano et al. 2005, Tena-Sempere 2006b, Brown et al. 2008).

Besides nutritional status, the photoperiod input is another of the most influential environmental cues modulating seasonal reproduction. In fact, in mammals, an environmental photoperiod is transduced by a photoneuroendocrine system composed of the retina, the suprachiasmic nucleus, and the pineal gland (Goldman 2001). The last of these releases the hormone melatonin exclusively at night so that the duration of secretion varies according to day length acting as the neurochemical expression of time (Goldman 2001, Simonneaux and Ribelayga 2003). In turn, melatonin modulates reproduction by regulating GnRH secretion, without acting directly upon the GnRH neurons (Malpaux et al. 2001). Instead, the mid-hypothalamus has been proposed as the site for melatonin action on reproduction, which is compatible with the localization of KiSS1 expression (Smith et al. 2005).

According to Clark et al. (2009), in seasonal breeders such as sheep, KP expression in the arcuate nucleus is markedly reduced during the non-breeding season, a physiological scenario which strongly suggests that the mechanisms that control seasonal changes in reproductive function involve KP-neurons. Since the non-breeding season is characterized by increased negative feedback of oestrogen on GnRH secretion, KP-neurons seem to be involved in the breeding status of seasonal-breeders.

In this respect, Revel et al. (2006) reported a significant role for the KiSS1/kisspeptin/GPR54 system in the control of seasonal reproduction, suggesting that the photoperiod, via melatonin secretion, modulates KiSS1 signalling to drive the reproductive axis. Certainly, according to Roseweir and Millar (2009), the KP-GPR54 complex has a great ability to co-ordinate mediation of many important signals relayed to the GnRH neuron such as positive and negative feedback, metabolic input and photoperiod; integrating in this way, signals from both internal and external sources.

According to Roa and Tena-Sempere (2007), while the characterization of the KiSS-1/GPR54 system in the control of essential aspects of female reproduction, from puberty to ovulation in 
mammalian species, has been extensively reported, its role in non-mammalian species remains largely unexplored. In this respect, Carrillo et al. (2009) reported the presence of GPR54 in GnRH neurons and changes in its expression during pubertal maturation in perciform fish species (sea bass), which is suggestive of a conserved function of this system during the evolution process of different species. Stronger evidence points to the KiSS-1-KP-GPR54 complex signalling as the main trigger of $\mathrm{GnRH}$ neuron activation and subsequent ovulation. Therefore, elucidation of the action pathways of this complex should generate new pharmacalogic strategies both for fertility and contraception treatments in the near future (Sills and Walsh 2008).

\section{CONCLUDING REMARKS}

Puberty is a developmental process that culminates in the acquisition of reproductive capability. This process is initiated with the release of GnRH from specialized hypothalamic neurons to stimulate hormonal cascades as well as gonadal activation. GnRH neurons are reasonably mature at birth, but, as the growth process starts, the pulsatile release of $\mathrm{GnRH}$ is suppressed. Later on, as the prepubertal phase approaches, inhibitory signals are diminished, while an increase in the pulsatile release of $\mathrm{GnRH}$ is observed. The last scenario results in a cascade of events with increases in synthesis and release of the hypophyseal gonadotrophins, LH and FSH, as well as an increase in ovarian function, particularly steroidogenesis and gametogenesis.

One of the most frequently invoked excitatory neuronal systems, for the neurotransmission and neuromodulatory processes during the establishment of the reproductive function is the kisspeptin and its GPR54 receptor. KP binds to its G-protein-coupled receptor GPR54, expressed in GnRH neurons, stimulating GnRH release and activation of the reproductive axis. Certainly, KP has been universally recognized as essential activator of the gonadotropic axis, with key roles in the onset of puberty as well as in the control of gonadotrophin secretion. Besides that, novel aspects of the KiSS-1, KP and GPR54 complex have pointed to this complex as a very effective sensory system which translates environmental cues into endocrine responses. The last includes its potential involvement in the neuroendocrine control of seasonal reproduction as well as acting as a metabolic gate for reproductive function, integrating in this way signals from internal and external environments. These novel actions of the
KiSS-1-KP-GPR54 complex acquire particular importance in the design of new reproductive and nutritional management technologies in seasonal breeders, such as sheep and goats, as well as in animal production systems under marginal conditions.

Interestingly, the expression of KiSS-1, mRNA and peptide, and its GPR54 receptor has recently been reported in the mammalian ovary, as well as in the establishment of the reproductive function in fish species. The last adds complexity to the potential action of this system in female reproduction in several species, emerging as a highly conserved reproductive system throughout the evolutionary process of multiple species. Understanding the reproductive axis, its development, activation and maintenance, has proved to be an important yet difficult assignment, due to the many regulatory components of this system. Further studies designed to elucidate the kisspeptin dependent-neural regulation of hypothalamic GnRH neurons, should gain new insights to better understand the establishment of the pubertal process, an exciting research area in both human and animal reproductive biology and neuroendocrinology.

\section{ACKNOWLEDGMENT}

This review was prepared within the outlined actions of the International Collaborative Projects “ C O N A C Y T - F O M I X - D U R A N G O, DGO-2008-C01-87559”, funded by the National Council of Science and Technology, Mexico, as well as “ALFA-III-ALAS, DCI-ALA/A9.09.01 /08/19189/161-358/ALFA-III-82”, supported by the European Union. The authors acknowledge financial support from these projects.

\section{REFERENCES}

Aparicio SA: Kisspeptins and GPR54: The new biology of the mammalian GnRH axis. Cell Metab 1:293-296, 2005.

Apter D: Development of the hypothalamic-pituitary-ovarian axis. Ann NY Acad Sci 816:9-21, 1997.

Apter D, Hermanson E: Update on female pubertal development. Curr Opin Obstet Gynecol 14:475-481, 2003.

Arechiga-Flores CF, Bañuelos-Valenzuela R, Rincon-Delgado RM, Meza-Herrera CA: Attainment of puberty in winter-born hair-ewe 
lambs under natural photoperiod (22 NL): Preliminary results. Wool Technol Sheep Breed 52:35-42, 2004.

Belsham DD, Lovejoy DA: Gonadotropin-releasing hormone: Gene evolution, expression and regulation. Vitam Horm 71:59-94, 2005.

Boukhliq R, Goodman RL, Berriman SJ, Adrian B, Lehman MN: A subset of gonadotropin-releasing hormone neurons in the ovine medial basal hypothalamus is activated during increased pulsatile luteinizing hormone secretion. Endocrinology 140:5929-5236, 1999.

Brown RE, Imran SA, Ur E, Wilkinson M: KiSS-1 mRNA in adipose tissue is regulated by sex hormones and food intake. Mol Cell Endocrinol 281:64-72, 2008.

Bronson FH: Puberty in female mice is not associated with increases in either body fat or leptin. Endocrinology 142:4758-4761, 2001.

Carrillo M, Zanuy S, Felip A, Bayarri MJ, Moles G, Gomez A: Hormonal and environmental control of puberty in perciform fish: the case of sea bass. Ann NY Acad Sci 1163:49-59, 2009.

Castellano JM, Navarro VM, Fernandez-Fernandez R, Noguerias R, Tovar S, Roa J, Tena-Sempere M: Changes in hypothalamic KiSS-1 system and restoration of pubertal activation of the reproductive axis by kisspeptin in undernutrition. Endocrinology 146:3917-3925, 2005.

Castellano JM, Gaytan M, Roa J, Vigo E, Navarro VM, Bellido C, Dueguez C, Aguilar E, Sanchez-Criado JE, Pellicer A, Pinilla L, Gaytan $F$ et al.: Expression of KiSS-1 in rat ovary: putative local regulator of ovulation? Endocrinology 147:4852-4862, 2006a.

Castellano JM, Navarro VM, Fernandez-Fernandez R, Castaño JP, Malagon MM, Aguilar E, Dieguez C, Magni P, Pinilla L, Tena-Sempere M: Ontogeny and mechanisms of action for the stimulatory effect of kisspeptin on gonadotropin-releasing hormon system in the rat. Mol Cel Endocrinol 257-258:75-83, 2006b.

Cheung CC, Thornton JE, Kuijper JL, Weigle DS, Clifton DK, Steiner RA: Leptin is a metabolic gate for the onset of puberty in the female rat. Endocrinology 138:855-857, 1997.

Clark IJ, Smith JT, Caraty A, Goodman RL, Lehman MN: Kisspeptin and seasonality in sheep. Peptides 30:154-163, 2009.

Clarke IJ, Pompolo S: Synthesis and secretion of GnRH. Anim Reprod Sci 88:29-55, 2005.

Clarkson J, Herbison AE: Development of GABA and glutamate signaling at the GnRH neuron in relation to puberty. Moll Cell Endocrinol 25:32-38, 2006.
DiVall SA, Radovick S: Endocrinology of female puberty. Curr Opin Endocrinol Diabetes Obes 16:1-4, 2009.

Ebling FJ: The neuroendocrine timing of puberty. Reproduction 129:675-683, 2005.

Gamez-Vazquez HG, Rosales-Nieto CA, Bañuelos-Valenzuela R, Urrutia-Morales J, Diaz-Gomez MO, Silva-Ramos JM, Meza-Herrera CA: Body condition score positively influence plasma leptin concentrations in criollo goats. J Anim Vet Adv 7:1237-1240, 2008.

Garcia-Segura LM, McCarthy MM: Minireview: role of glia in neuroendocrine function. Endocrinology 145:1082-1086, 2004.

Gill JC, Moenter SM, Tsai PS: Developmental regulation of gonadotropin-releasing hormone neurons by fibroblast growth factor signalling. Endocrinology 145:3830-3839, 2004.

Goldman BD: Mammalian photoperiodic system: Formal properties and neuroendocrine mechanisms of photoperiodic time measurement. J Biol Rhythms 16:283-301, 2001.

Gottsch ML, Clifton DK, Steiner RA: Kisspeptin-GPR54 signaling in the neuroendocrine reproductive axis. Mol Cell Endocrinol 25:91-96, 2006.

Guerra-García M, Meza-Herrera CA, Sanchez-Torres-Esqueda MT, Gallegos-Sanchez J, Torres-Hernandez G, Pro-Martinez A: IGF-1 and ovarian activity of goats in divergent body condition and supplemented with non-degradable ruminal protein. Agrociencia 4:241-247, 2009.

Gutierrez-Pascual E, Martinez-Fuentes AJ, Pinilla L, Tena-Sempere M, Malagon MM, Castano JP: Direct pituitary effects of kisspeptin: activation of gonadotrophs and somatothrops and stimulation of luteinizing hormone and growth hormone secretion. J Neuroendocrinol 19:521-530, 2007.

Heger S, Mastronardi C, Dissen GA, Lomniczi A, Cabrera R, Roth CL, Jung H, Calimi F, Sippell W, Ojeda SR: Enhanced at puberty 1 (EAP1) is a new transcriptional regulator of the female neuroendocrine axis. J Clin Invest 117:2145-2154, 2007.

Hughes IA, Kumanan M: A wider perspective on puberty. Moll Cell Endocrinol 25:1-7, 2006.

Jimenez-Linan M, Rubin BS, King JC: Examination of guinea pig luteinizing hormone-releasing hormone gene reveals a unique decapeptide and existence of two transcripts in the brain. Endocrinology 138:4123-4130, 1997.

Kadokawa H, Suzuki S, Hashizume T: Kisspeptin-10 stimulates the secretion of growth hormone and prolactin directly from cultures bovine anterior pituitary cells. Anim Reprod Sci 105:404-408, 2008. 
Kotani M, Detheux M, Vandebogaerde A, Communi D, Vanderwinden JM, Blanpain C, Schiftfmann SN, Vassart G, Parmentier M: The metastasis suppressor gene KiSS1 encodes kisspeptins, the natural ligands of the orphan $G$ protein-coupled receptor GPR54. J Biol Chem 276:34631-34636, 2001.

Latimer VS, Rodrigues SM, Grayfallou VT, Kphama SG, White RB, Frenald RD, Urbanski HF: Two molecular forms of gonadotropin-releasing hormone (GnRH-I and GnRH-II) are expressed by two separate populations of cells in the rhesus macaque hypothalamus. Brain Res Mol Brain Res 75:287-292, 2000.

Lehman MN, Robinson JE, Karsch FJ, Silverman AJ: Immunocytochemical localization of luteinizing hormone-releasing hormone (LHRH) pathways in the sheep brain during anestrus and the mid-luteal phase of the estrous cycle. J Comp Neurol 244:19-35, 1986.

Lee DK, Nguyen T, O’Neill GP, Cheng R, Liu Y, Howard AD, Coulombe N, Tan CP, Tang-Nguyen AT, George SR, O’Dowd BF: Discovery of a receptor related to galanin receptors. FEBS Lett 446:103-107, 1999.

Maffucci JA, Gore AC: Hypothalamic neural systems controlling the female reproductive life cycle: Gonadotropin-releasing hormone, glutamate and GABA. In Kwang WJ (ed.): International Review of Cell and Molecular Biology, Vol. 274, Academic Press, Burlington 2009, pp. 69-127.

Malpaux B, Migaud M, Tricoire H, Chemineau P: Biology of mammalian photoperioidism and the critical role of the pineal gland and melatonin. $\mathrm{J}$ Biol Rhythms 16:336-347, 2001.

Marshall PE, Goldsmith PC: Neuroregulatory and neuroendocrine $\mathrm{GnRH}$ pathways in the hypothalamus and forebrain of the baboon. Brain Res 193:357-372, 1980.

Messinis IE: From menarche to regular menstruation: Endocrinological background. Ann NY Acad Sci 1042:49-56, 2006.

Meza-Herrera CA, Sanchez JM, Chavez-Perches JG, Salinas H, Mellado M: Protein supplementation, body condition and ovarian activity in goats. Preovulatory serum profile of insulin. S Afr J Anim Sci 34:223-226, 2004.

Meza-Herrera CA, Ross T, Hallford DM, Hawkins D, Gonzalez-Bulnes A: Effects of body condition and protein supplementation on LH secretion and luteal function in sheep. Reprod Domest Anim 42:461-465, 2007.

Meza-Herrera CA, Hallford DM, Ortiz JA, Cuevas RA, Sanchez JM, Salinas H, Mellado M, Gonzalez-Bulnes A: Body condition and protein supplementation positively affect periovulatory ovarian activity by non-LH mediated pathways in goats. Anim Reprod Sci 106:412-420, 2008.

Meza-Herrera CA, Gonzalez-Bulnes A, Kridli R, Mellado M, Arechiga-Flores CF, Salinas H, Luginbhul JM: Neuroendocrine, metabolic and genomic cues signaling the onset of puberty in females. Reprod Domest Anim 2009. doi: 10.1111/j.1439-0531.2009.01355.x

Mikkelsen JD, Simonneaux V: The neuronantomy of the kisspeptin system in the mammalian brain. Peptides 30:26-33, 2009.

Muir AI, Chamberlain L, Elshourbagy A, Michalovich D, Moore DJ, Calamari A, Szekeres PG, Sarau HM, Chambers JK, Murdock P, Steplewski K, Shabon U et al.: AXOR12, a novel human $\mathrm{G}$ protein-coupled receptor, activated by the peptide KiSS1. J Biol Chem 276:28969-28975, 2001.

Muñoz-Gutierrez M, Findlay PA, Adam CL, Wax G, Campbell BK, Kendall NR, Khalid M, Forsberg M, Scaramuzzi RJ: The ovarian expression of mRNAs for aromatase, IGF-I receptor, IGFbinding protein-2, 4 and 5, leptin receptor in cycling ewes after three days of leptin infusion. Reproduction 130:869-881, 2005.

Ojeda SR, Roth C, Mungenast A, Heger S, Mastronardi C, Parent AS, Lomniczi A, Jung H: Neuroendocrine mechanisms controlling female puberty: new approaches, new concepts. Int J Androl 29:286-290, 2006a.

Ojeda SR, Lomniczi A, Mastronardi C, Heger S, Roth C, Parent AS Matagne V, Mungenast AE: The neuroendocrine regulation of puberty: Is time ripe for a systems biology approach? Endocrinology 147:1166-1174, 2006b.

Popa SM, Clifton DK, Steiner RA: A KiSS to remember. Trends Endocrinol Metab 16:249-250, 2005.

Prevot V, Dehouck B, Poulain P, Beauvillain JC, Bue e-Scherrer V, Bouret S : Neuronal-glial-endotelial interactions and cell plasticity in the postnatal hypothalamus: Implications for the neuroendocrine control of reproduction. Psychoneuroendocrinology 32:546-551, 2007.

Ramakrishnappa N, Rajamadhendran N, Yung-Ming, L, Leung PCK: GnRH in non-hypothalamic reproductive tissues. Anim Reprod Sci 88:95-113, 2005.

Revel FT, Saboureau, M, Masson-Pevet M, Pevet P, Mikkelsen JD, Simonneaux V: Kisspeptin mediates the photoperiodic control of reproduction in hamsters. Curr Biol 16:1730-1735, 2006. 
Roa J, Tena-Sempere M: KiSS-1 system and reproduction: comparative aspects and roles in the control of female gonadotropic axis in mammals. Gen Comp Endocrinol 153:132-140, 2007.

Roseweir AK, Millar RP: The role of kisspeptin in the control of gonadotrophin secretion. Hum Reprod Update 15:203-212, 2009.

Roth C, Schricker M, Lakomek M, Strege A, Heiden I, Luft H, Munzel U, Wuttke W, Jarry H: Autoregulation of the gonadotropin-releasing hormone $(\mathrm{GnRH})$ system during puberty: effects of antagonistic versus agonistic GnRH analogs in a female rat model. J Endocrinol 169:361-371, 2001.

Scaramuzzi RJ, Campbell BK, Downing JA, Kendall NR, Khalid M, Muñoz-Gutierrez M, Somchit A: A review of the effects of suplementary nutrition in the ewe on the concentrations of reproductcive and metabolic hormones and the mechanisms that regulate folliculogenesis and ovulation rate. Reprod Nutr Dev 46:339-354, 2006.

Sills ES, Walsh AP: The GPR54-Kisspeptin complex in reproductive biology: neuroendocrine significance and implications for ovulation induction and contraception. Neuro Endocrinol Lett 29:846-851, 2008.

Simonneaux V, Ribelayga C: Generation of the melatonin endocrine message in mammals: A review of the complex regulation of melatonin synthesis by norepinephrine, peptides and other pineal transmitters. Pharmacol Rev 55:325-395, 2003.

Singh R, Graves ML, Roskelly CD, Giritharan G, Rajamahendran M: Gonadotropin releasing hormone receptor gene and protein expression and immunohistochemical localization in bovine uterus and oviducts. Domest Anim Endocrinol 34:319-326, 2008.

Smith JT, Dungan HM, Stoll EA, Gottsch ML, Braun RE, Eacker SM, Clifton DK, Steiner RA: Differential regulation of KiSS1 mRNA by sex steroids in the brain of the male mouse. Endocrinology 146:2976-2984, 2005.
Suttie JM, Kostyo JL, Ebling FJ, Wood RI, Bucholtz DC, Skottner A, Adel TE, Towns RJ, Foster DL: Metabolic interphases between growth and reproduction. IV. Chronic pulsatile administration of growth hormone and the timing of puberty in sheep. Endocrinology 129:2024-2032, 1998.

Suzuki S, Kadokawa H, Hashizume T: Direct kisspeptin-10 stimulation on luteinizing hormone secretion from bovine and porcine anterior pituitary cells. Anim Reprod Sci 3:360-365, 2008.

Tena-Sempere M: The roles of kisspeptins and G-protein-coupled receptor 54 in pubertal development. Curr Opin Pediatr 18:442-447, 2006a.

Tena-Sempere M: KISS-1 and reproduction: Focus on its role in the metabolic regulation of fertility. Neuroendocrinology 83:275-281, 2006b.

Tena-Sempere M: GPR54 and kisspeptin in reproduction. Hum Reprod Update 12:631-639, 2006c.

Teresawa E: Role of GABA in the mechanism of the onset of puberty in non-human primates. Int Rev Neurobiol 71:113-129, 2005.

Terasawa E, Fernandez DL: Neurobiological mechanisms of the onset of puberty in primates. Endocr Rev 22:111-151, 2001.

Veliz FG, Meza-Herrera CA, de Santiago-Miramontes MA, Arellano-Rodriguez G, Leyva C, Rivas-Muñoz R, Mellado M: Effect of parity and progesterone priming on induction of reproductive function in Saanen goats by buck exposure. Livest Sci 125:261-265, 2009.

Whitlock KE, Illing N, Brideau NJ, Smith KM, Twomey S: Development of GnRH cells: Setting the stage for puberty. Moll Cell Endocrinol 25:39-50, 2006.

Wray S: Development of luteinizing hormone releasing neurons. J Neuroendocrinol 13:2-11, 2001.

Zapatero-Caballero H, Sanchez-Franco F, Fernandez-Mendez C, Garcia-Sanrutos M, Botella-Cubells LM, Fernandez-Vazquez G: Gonadotropin-releasing hormona expresión during pubertal development in rats. Biol Reprod 70:348-355, 2004. 